\title{
Evaluasi Kesesuaian Lahan Untuk Tipe Penggunaan Lahan Tanaman Pangan Lahan Kering Di Daerah Aliran Sungai Wae Batu Merah Kota Ambon Provinsi Maluku
}

\author{
Land Evaluation of Food Crops Upland Landuse Types on Wae Batu Merah Watershed Ambon \\ City, Maluku Province
}

\section{Daniel Torimtubun ${ }^{1}$, Ellisa J. Gaspersz², Rafael M. Osok ${ }^{2, *}$, Silwanus, M. Talakua ${ }^{2}$}

${ }^{1}$ Program Studi Agroteknologi, Jurusan Budidaya Pertanian, Fakultas Pertanian, Universitas Pattimura Jln. Ir. M. Putuhena, Kampus Poka Ambon 97233

${ }^{2}$ Jurusan Budidaya Pertanian, Fakultas Pertanian, Universitas Pattimura

Jln. Ir. M. Putuhena, Kampus Poka Ambon 97233

*Penulis Korespondensi: E-mail: rafael_osok@yahoo.com

\begin{abstract}
The study was conducted on Wae Batu Merah watershed in Ambon, from July to October 2016, with the covered area of 685,14 ha. The objectives of the study were 1) to determine the limiting factors of land suitability classes of the upland food crops land-use types, and 2) to establish the land suitability classes of the upland food crops land-use types. The study method was surveyed with a synthetic approach and filed data collection was conducted using distanced-flexible observation. The study shows that there are two land sutability classes on the Wae Batu Merah, namely marginal (S3) land sutability class covered area of 116,93 ha or 17,06\% and not-suitable (N) land suitability class covered area of 568,21 ha or $82,94 \%$, while there are seven limiting factors, namely effective soil depth, soil texture, soil drainage, slope steepness, soil pH, soil erodibility. The application of terracing, mulching and contour planting are recommended to reduce the effect of slope steepness and soil erodibility.
\end{abstract}

Keywords: Ambon city, land suitability class, wae batu merah watershed

\section{ABSTRAK}

Penelitian ini dilaksanakan di DAS Wae Batu Merah Kota Ambon Provinsi Maluku pada bulan Juli sampai Oktober 2016 dengan luas lokasi penelitian 685,14 ha. Penelitian ini dilaksankan dengan tujuan : 1) Menetapkan faktorfaktor pembatas tingkat kesesuaian lahan untuk tipe penggunaan lahan tanaman pangan lahan kering di DAS Wae Batu Merah Kota Ambon, 2) Menetapkan kesesuaian lahan untuk tipe penggunaan lahan tanaman pangan lahan kering di DAS Wae Batu Merah Kota Ambon, Metode penelitian yang digunakan adalah metode survey dengan pola pendekatan sintetik dan jarak observasi fleksibel mengikuti perubahan bentuk fisiografi dan penggunaan lahan. Berdasarkan hasil pengamatan lapangan dengan evaluasi lahan, hasil yang di temukan adalah: 1) terdapat 2 kelas kesesuaian lahan pada Das Wae Batu Merah yaitu, kelas kesesuaian lahan S3 terdapat pada area seluas $116.93 \mathrm{Ha}$ atau 17.06\%, dan kelas kesesuaian $\mathrm{N}$ terdapat pada area seluas $568.21 \mathrm{Ha}$ atau $82.94 \%$, 2) Berdasarkan hasil evaluasi lahan maka terdapat 7 faktor pembatas yaitu kedalaman efektif, tekstur tanah, drainase, kemiringan lereng, $\mathrm{pH}$ tanah, erodibilitas, zona agroklimat. Kelas kesesuaian lahan potensial setelah dilakukan perbaikan dari S3 menjadi S2 dengan faktor pembatas $\mathrm{pH}$ tanah, lereng, dan erodibilitas. untuk faktor pembatas drainase dapat diatasi dengan pembuatan saluran drainase, untuk lereng dan erodibilitas dapat diatasi dengan pembuatan teras, dan penanaman sejajar kontor dan penanaman tanaman penutup tanah.

Kata kunci: daerah aliran sungai wae batu merah, evaluasi lahan, kota Ambon

\section{PENDAHULUAN}

Lahan merupakan salah satu sumber daya alam yang tidak terbaharui (unrenewable), dan hampir semua sektor pembangunan fisik membutuhkan lahan (Sitorus, 1985). Menurut Hardjowigeno dan Widiatmaka (2007), lahan mempunyai peranan sangat penting bagi kehidupan manusia karena segala macam bentuk intervensi manusia baik untuk pembangunan maupun untuk memenuhi kebutuhan hidupnya berasal dari lahan dalam bentuk penggunaan lahan atau land use. Oleh sebab itu, pertumbuhan penduduk menjadi salah satu faktor pendorong peningkatan kebutuhan lahan yang diperuntukan untuk tempat tinggal, sarana penunjang 
kehidupan, industri, dan pertanian (Nganji, 2018). Sakar et al. (2014) mengatakan bahwa pertumbuhan penduduk dan meningkatnya kebutuhan lahan pertanian untuk memenuhi ketersedian pangan merupakan penyebab terjadinya perubahan (konversi) penggunaan lahan yang berakibat pada menurunnya produktivitas lahan dan meningkatnya degradasi lahan akibat erosi (Panagosa et al., 2015). Sedangkan menurut Sitorus et al. (2011) konversi lahan yang dianggap sebagai penyebab munculnya kerusakan lingkungan di Indonesia.

Wilayah Kota Ambon pada dasarnya terbentuk dari Daerah-daerah aliran sungai (DAS) dengan batas punggung bukit yang membedahkan satu DAS dengan DAS lainnya. Oleh sebab itu perencanaan penggunaan lahan di wilayah kota Ambon pada dasarnya adalah perencanaan penggunaan lahan di DAS (Osok et al., 2018). Kondisi sumberdaya lahan kering yang sangat beragam (iklim, geologi, tanah, dan penggunaan lahan) dan secara khususnya topografi wilayah kota Ambon yang didominasi oleh kemiringan lereng $>45 \%$ menjadi faktor pembatas yang sangat penting dalam menentukan pola penggunaan lahan dan teknologi pengelolaan lahan di wilayah kota Ambon, seperti tindakan konservasi tanah dan rehabilitasi lahan.

DAS Wae Batu Merah merupakan salah satu DAS di kota Ambon yang perlu mendapatkan perhatian khusus karena telah terjadi penurunan kualitas dari DAS tersebut. Hasil penelitian Manuputty (2017) di DAS Wae Batu Merah menunjukkan bahwa daya dukung DAS (DDD) Batu Merah tergolong buruk (nilai DDD = 111) dan nilai indeks fungsi lindung DAS tinggi $(2,99)$ yang berarti fungsi DAS sebagai pengatur tata air sudah terganggu. Sedangkan hasil penelitian kemampuan lahan (Osok et al., 2018) menunjukan bahwa 52,58\% wilayah DAS Wae Batu Merah masuk dalam kemampuan lahan kelas VIII yang berarti lahan-lahan ini peruntukannya lebih diarahkan untuk kawasan lindung dan konservasi.

Penurunan kualitas DAS ini diakibatkan karena (a) semakin meningkatnya jumlah penduduk yang tinggal dalam lingkungan DAS Wae Batu Merah yang berakibat timbulnya masalah kulaitas air, seperti pencemaran air, banjir dan kekeringan, dan (b) yang semakin meningkatnya pemanfaatan lahan untuk tanaman pangan lahan kering seperti ubi kayu dan ubi jalar dan jagung di wilayah DAS Wae Batu Merah. Usaha tanaman pangan lahan kering ini (ubi kayu, ubi jalar dan jagung) masih bersifat tradisional (bakar lahan dan olah tanah secara kuming) yang dilakukan terutama pada lahan-lahan dengan kerimiringan lereng 30\% hingga $>45 \%$ sehingga ancaman kerusakan tanah akibat erosi sangat tinggi. Namun sebaliknya, hingga saat ini belum ada kajian yan dilakukan pada DAS Wae Batu Merah terkait dengan kesesuaian lahan khususnya kesesuaian lahan untuk tanaman pangan lahan kering yang hasilnya dapat memberi arahan pemanfaatan lahan secara baik di DAS Wae Batu Merah.

Dengan pertimbangan diatas, maka penelitian ini secara khusus menfokuskan diri pada penetapan kesesuaian lahan bagi tanaman pangan lahan kering yang diharapkan hasil penelitian ini dapat menjadi arahan untuk pengembangan tanaman umbi kayu, ubi jalar dan jagung di DAS Wae Batu Merah sesuai dengan kesesuaian lahannya dan mampu mengurangi dampak kerusakan tanah akibat erosi.

\section{METODE PENELITIAN}

Penelitian ini dilaksanakan di DAS Wae Batu Merah Kota Ambon Provinsi Maluku dari bulan Juli sampai Oktober 2016. Peralatan yang digunakan dalam penelitian ini adalah Kompas, abney level, altimeter, soil munsell colour chart, Soil tester, kartu deskripsi profil, parang, cangkul, Indikator $\mathrm{pH}$, Bor, pisau lapangan, GPS, dan alat tulis menulis. Bahan yang digunakan yaitu $\mathrm{H}_{2} \mathrm{O}_{2}, \mathrm{HCl}$ dan Akuades.

\section{Pekerjaan Persiapan}

Pelaksanaan tahap pekerjaan persiapan meliputi: pengumpulan data tentang daerah penelitian, membuat peta unit lahan sebagai peta kerja, mempersiapkan alat dan bahan yang digunakan serta mempersiapkan administrasi perjalanan dan kebutuhan logistik.

\section{Pekerjaan Lapangan}

Metode yang digunakan adalah metode survei dengan pola pendekatan sintetik dan jarak observasi fleksibel pada jalur-jalur pengamatan yang mewakili unit lahan pada lokasi penelitian. Pengamatan sifat morfologi tanah dilakukan melalui pengamatan boring, selanjutnya berdasarkan sebaran data boring ini ditetapkan lokasi profil pewakil untuk setiap jenis tanah dan pengambilan sampel untuk analisis.

\section{Analisis Laboratorium}

Analisis tanah dilakukan di laboratorium tanah, Balai Penelitian Tanah Bogor, meliputi tekstur tanah, kandungan $\mathrm{C}$-organik, $\mathrm{pH}, \mathrm{N}, \mathrm{P}, \mathrm{K}$ tersedia, basa-basa, KTK, dan KB.

\section{Pengolahan Data dan Penyusunan}

Kegiatan pada tahap ini meliputi: 1) memperbaiki peta satuan lahan yang telah dibuat sebelumnya berdasarkan hasil pengamatan lapangan dengan skala $1: 15.000 ; 2$ ) membuat tabulasi dan data lapangan dan data laboratorium; 3) Penentuan evaluasi kesesuaian lahan untuk tipe penggunaan pertanian lahan kering yang dilakukan dengan membandingkan data hasil pengamatan lapangan dan hasil analisi laboratorium dengan kriteria evaluasi kesesuaian lahan untuk tipe penggunaan pertanian lahan kering (Tabel 1) dan membuat peta kesesuaian lahan DAS Wae Batu Merah. 
Tabel 1. Kriteria kesesuaian lahan untuk Tanaman Pangan Lahan Kering

\begin{tabular}{|c|c|c|c|c|c|c|c|}
\hline \multirow{2}{*}{ No. } & \multirow{2}{*}{ Parameter } & \multirow{2}{*}{ Simbol } & \multicolumn{5}{|c|}{ Kelas kesesuaian } \\
\hline & & & $\mathrm{S} 1$ & S2 & S3 & $\mathrm{N} 1$ & $\mathrm{~N} 2$ \\
\hline 1. & $\begin{array}{c}\text { Kedalam } \\
\text { efektif }\end{array}$ & $\mathrm{S}$ & $>75 \mathrm{~cm}$ & $>50 \mathrm{~cm}$ & $>25 \mathrm{~cm}$ & $>10 \mathrm{~cm}$ & \\
\hline 2. & $\begin{array}{l}\text { Kelas besar } \\
\text { butir pada } \\
\text { zona } \\
\text { perakaran }\end{array}$ & $\mathrm{s}$ & $\begin{array}{c}\text { Berliat, berdebu } \\
\text { halus, } \\
\text { berlempung } \\
\text { halus }\end{array}$ & $\begin{array}{l}\text { Berliat, berdebu halus, berlempung } \\
\text { halus }\end{array}$ & $\begin{array}{c}\text { Berliat, berdebu halus dan } \\
\text { kasar, berlempung halus }\end{array}$ & $\begin{array}{c}\text { Berliat, berdebu halus } \\
\text { dan kasar, berpasir (bukan } \\
\text { kuarsa) berskeletal }\end{array}$ & \\
\hline 3. & $\begin{array}{l}\text { Batu-batu di } \\
\text { permukaan } \\
\text { tanah }\end{array}$ & $\mathrm{s}$ & $<5 \%$ & $<25 \%$ & $<50 \%$ & $<75 \%$ & $\stackrel{\pi}{己}$ \\
\hline 4. & $\begin{array}{l}\text { Kesuburan } \\
\text { tanah }\end{array}$ & $\mathrm{n}$ & Tinggi & Tinggi, sedang & Tinggi, sedang, rendah & $\begin{array}{l}\text { Tinggi sedang, rendah } \\
\text { dan sangat rendah }\end{array}$ & . \\
\hline 5. & $\begin{array}{l}\text { Reaksi tanah } \\
\text { lapisan atas } \\
(0-30 \mathrm{~cm})\end{array}$ & $\mathrm{a}$ & pH 6,0-7,0 & $\mathrm{pH} 5,5-7,5$ & $\mathrm{pH} 4,5-8,0$ & pH $3,5-8,5$ & હ \\
\hline 6. & Toksisitas & e & & & & & 족 \\
\hline & $\begin{array}{c}\text { c.kej. Al d. } \\
\text { Ked. Pirit }\end{array}$ & & $<20 \%$ & $<40 \%$ & $<60 \%$ & $<80 \%$ & च \\
\hline 7. & $\begin{array}{l}\text { Lereng dan } \\
\text { keadaan } \\
\text { permukaan } \\
\text { tanah }\end{array}$ & $\mathrm{t}$ & $<3 \%$ & $<3 \%$ & $<8 \%$ & $<15 \%$ & 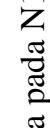 \\
\hline 8. & $\begin{array}{l}\text { Ketinggian } \\
\text { tempat }\end{array}$ & $\mathrm{h}$ & $\mathrm{Tdml}<500 \mathrm{~m}$ & $\mathrm{Tdml}<750 \mathrm{~m}$ & $\mathrm{Tdml}<1000 \mathrm{~m}$ & $\mathrm{Tdml}<1000 \mathrm{~m}$ & $\stackrel{\mathscr{E}}{\mathscr{E}}$ \\
\hline 9. & $\begin{array}{l}\text { Erodibilitas } \\
\text { tanah }\end{array}$ & $\mathrm{e}$ & Sangat rendah & Sangat rendah, rendah & $\begin{array}{l}\text { Sangat rendah, rendah, } \\
\text { sedang }\end{array}$ & $\begin{array}{l}\text { Sangat rendah, } \\
\text { rendah, sedang, } \\
\text { agak tinggi, tinggi }\end{array}$ & E \\
\hline 10. & $\begin{array}{c}\text { Zona } \\
\text { agroklimat } \\
\text { (oldeman } e t \\
\text { al.) }\end{array}$ & $\mathrm{c}$ & $\mathrm{A} 1, \mathrm{~A} 2, \mathrm{~B} 1, \mathrm{~B} 2$ & $\mathrm{~A} 1, \mathrm{~A} 2, \mathrm{~B} 1, \mathrm{~B} 2, \mathrm{~B} 3$ & $\begin{array}{c}\mathrm{A} 1, \mathrm{~A} 2, \mathrm{~B} 2, \mathrm{~B} 3, \mathrm{C} 2, \mathrm{C} 3, \mathrm{D} 2, \\
\mathrm{D} 3\end{array}$ & $\begin{array}{c}\mathrm{B} 1, \mathrm{~A} 1, \mathrm{~A} 2, \mathrm{~B} 1, \mathrm{~B} 2, \mathrm{~B} 3, \\
\mathrm{C} 1, \mathrm{C} 2, \mathrm{C} 1, \mathrm{C} 3, \mathrm{D} 1, \mathrm{D} 2, \\
\mathrm{D} 3, \mathrm{E} 1, \mathrm{E} 2, \mathrm{E} 3, \mathrm{D} 1\end{array}$ & \\
\hline 11. & $\begin{array}{l}\text { Kelas } \\
\text { drainase }\end{array}$ & $\mathrm{d}$ & Baik & Baik & Agak baik & $\begin{array}{c}\text { Cepat, agak cepat, baik, } \\
\text { agak terhambat, } \\
\text { terhambat }\end{array}$ & \\
\hline 12. & $\begin{array}{l}\text { Banjir dan } \\
\text { genangan } \\
\text { musiman }\end{array}$ & f & Tanpa & $\begin{array}{l}\text { Kurang dari } 2 \text { bulan dengan tanpa } \\
\text { adanya genangan permanen }(<1 \mathrm{~m})\end{array}$ & $\begin{array}{c}\text { Kurang dari } 4 \text { bulan } \\
\text { dengan tanpa adanya } \\
\text { genangan permanen } \\
(<1 \mathrm{~m})\end{array}$ & $\begin{array}{c}\text { Kurang dari } 4 \text { bulan } \\
\text { dengan genangan } \\
\text { permanen }(1 \mathrm{~m})\end{array}$ & \\
\hline 13. & $\begin{array}{c}\text { Salinitas } \\
(\mathrm{mmhos} / \mathrm{cm})\end{array}$ & $\mathrm{x}$ & $<1500$ & $<2500$ & $<4000$ & $<4000$ & \\
\hline
\end{tabular}

Sumber: Hardjowigeno dan Widiatmaka (2007)

\section{HASIL DAN PEMBAHASAN}

\section{Letak dan Luas Lokasi Penelitian}

Secara geografis DAS Wae Batu Merah terletak pada posisi $3^{\circ} 40^{\prime} 45,14^{\prime \prime}$ 'LS $3^{\circ} 42^{\prime} 18,89^{\prime}$ 'LS dan $128^{\circ} 10^{\prime} 58,33^{\prime \prime}$ 'BT $128^{\circ} 13^{\prime} 21,39^{\prime}$ 'BT. Sedangkan secara administratif, DAS Wae Batu Merah masuk dalam wilayah Negeri Batu Merah Kecamatan Sirimau Kota Ambon. Luas DAS Wae Batu Merah adalah 685,14 ha.

\section{Topografi}

Tabel 2 menunjukkan bahwa DAS Wae Batu Merah didominasi oleh topografi miring dengan luas 188,51 ha atau $27,51 \%$, diikuti oleh topografi agak miring dengan luas 167,83 ha atau $24,50 \%$, landai dengan luas 149,94 ha atau $21,88 \%$ dan datar dengan luas 118,49 ha atau $17,29 \%$. Topografi yang memiliki luasan tidak terlalu besar adalah topografi agak curam dengan luas 51,54 ha atau 7,52 \%, sedangkan topografi yang memiliki luasan paling kecil adalah topografi curam dengan luas 8,83 ha atau $1,29 \%$.

\section{Geologi}

Geologi DAS Wae Batu Merah didominasi oleh formasi geologi Tpav dengan luas 401,87 ha atau $58,66 \%$. Formasi geologi Tpav adalah batuan gunung api ambon yang berupa material lepas yang tersusun dari batuan andesit, dasit, breksi tuf. Formasi lainnya adalah batuan gamping koral dengan luas penyebaran 246,53 ha atau $35,98 \%$. Formasi yang memiliki luas penyebaran paling kecil di DAS Wae Batu Merah adalah bahan aluvium dengan luas penyebaran 36,73 ha atau 5,36 \%. Bahan aluvium merupakan endapan marin (Tabel 3).

\section{Tanah}

Tabel 4 menunjukkan bahwa jenis tanah kambisol memiliki luas yang paling besar yaitu 323,41 ha atau 47,20\%. Tanah Kambisol berkembang terutama dari formasi geologi batuan gunung api Ambon (Tpav) serta bahan induk konglomerat. Jenis tanah podsolik dengan luas 238,47 ha atau $34,81 \%$ berkembang terutama dari formasi geologi batuan gunung api Ambon serta bahan induk konglomerat. 
Tabel 2. Karakteristik topografi DAS Wae Batu Merah

\begin{tabular}{|c|c|c|c|c|c|}
\hline \multirow{2}{*}{ No. } & \multirow{2}{*}{ Kelerengan } & \multirow{2}{*}{ Kelas Topografi } & \multirow{2}{*}{ Kode } & \multicolumn{2}{|c|}{ Luas } \\
\hline & & & & Ha & $\%$ \\
\hline 1. & $0-3 \%$ & Datar & L0 & 118,49 & 17,29 \\
\hline 2. & $3-8 \%$ & Landai & L1 & 149,94 & 21,88 \\
\hline 3. & $8-15 \%$ & Berombak & $\mathrm{L} 2$ & 167,83 & 24,50 \\
\hline 4. & $15-30 \%$ & Bergelombang & L3 & 188,51 & 27,51 \\
\hline 5. & $30-45 \%$ & Agak curam & L4 & 51,54 & 7,52 \\
\hline 6. & $45-65 \%$ & Curam & L5 & 8,83 & 1,29 \\
\hline \multicolumn{4}{|c|}{ Total Luas DAS Wae Batu Merah } & 685,14 & 100,00 \\
\hline
\end{tabular}

Sumber: Penelitian lapangan, 2016.

Tabel 3. Formasi geologi DAS Wae Batu Merah

\begin{tabular}{|c|c|c|c|c|c|}
\hline \multirow{2}{*}{ No. } & \multirow{2}{*}{ Formasi Geologi } & \multirow{2}{*}{ Litologi } & \multirow{2}{*}{ Kode } & \multicolumn{2}{|c|}{ Luas } \\
\hline & & & & Ha & $\%$ \\
\hline 1. & Qa & Aluvium & $\mathrm{a}$ & 36,73 & 5,36 \\
\hline 2. & Q1 & Gamping koral & b & 246,53 & 35,98 \\
\hline 3. & Tpav & Gunung Api & c & 401,87 & 58,66 \\
\hline \multicolumn{4}{|c|}{ Total Luas DAS Wae Batu Merah } & 685,14 & 100,00 \\
\hline
\end{tabular}

Sumber: Penelitian lapangan, 2016.

Tabel 4. Jenis tanah di DAS Wae Batu Merah

\begin{tabular}{|c|c|c|c|c|c|}
\hline \multirow{2}{*}{ No. } & \multicolumn{2}{|c|}{ Klasifikasi Macam Tanah } & \multirow{2}{*}{ Kode } & \multicolumn{2}{|c|}{ Luas } \\
\hline & PPT 1983 & USDA 2006 & & Ha & $\%$ \\
\hline 1. & Aluvial & Typic Fluvaquents & A & 36,73 & 5,36 \\
\hline 2. & Gleisol & Thapto-Histic Hydraquents & $\mathrm{B}$ & 0,53 & 0,08 \\
\hline 3. & Rendzina & Lithic Haprendolls & $\mathrm{D}$ & 71,78 & 10,48 \\
\hline 4. & Litosol & Lithic Udorthents & $\mathrm{E}$ & 14,15 & 2,07 \\
\hline 5. & Kambisol & Lithic Eutrudepts & $\mathrm{G}$ & 323,49 & 47,20 \\
\hline 6. & Podsolik & Typic Rhodudults & $\mathrm{H}$ & 238,49 & 34,81 \\
\hline \multicolumn{4}{|c|}{ Total Luas DAS Wae Batu Merah } & 685,14 & 100,00 \\
\hline
\end{tabular}

Sumber: Penelitian lapangan, 2016

Tanah rendzina dengan luas 71,78 ha atau 10,48 $\%$ berkembang dari formasi gamping koral, serta jenis tanah aluvial memiliki luas 36,73 ha atau 5,36 \% dari luas DAS. Tanah aluvial merupakan tanah yang belum berkembang dan menunjukan pengendapan berlapis (bergantian antara pasir halus dan agak kasar-kasar) pada lapisan tanah mengikuti kedalaman solum. Tanah ini berkembang dari pada formasi geologi aluvium. Jenis tanah litosol dengan luas 14,15 ha atau 2,07 \% dari luas DAS mempunyai kedalaman solum yang dangkal-sangat dangkal $(0-24 \mathrm{~cm})$ dan pada lapisan bawahnya dijumpai batuan induk/ bahan induk. Tanah ini ditemukan pada daerah miring yang didominasi oleh batuan gunung api Ambon, dan sedikit pada formasi geologi bahan induk konglomerat. Jenis tanah gleisol memiliki luas persebaran yang paling kecil yaitu 0,53 ha atau $0,08 \%$. Tanah ini merupakan tanah yang berkembang dari bahan induk Tpav pada daerah cekungan (depresi) dengan vegetasi utama yaitu vegetasi sagu.

\section{Penggunaan Lahan}

Tipe penggunaan lahan di DAS Wae Batu Merah didominasi oleh permukiman dengan luas 408,26 ha atau 59,59\%. Selanjutnya diikuti oleh tipe penggunaan lahan semak belukar dengan luas 215,42 ha atau 31,44 \%. Tipe penggunaan lahan terkecil di DAS Wae Batu Merah adalah hutan lahan kering sekunder dengan luas 61,46 ha atau $8,97 \%$ (Tabel 5).

\section{Unit Lahan di DAS Wae Batu Merah}

Satuan analisis yang digunakan dalam penelitian ini adalah peta unit lahan yang diperoleh dari hasil tumpang tindih (overlay) antara peta topografi, peta geologi, peta jenis tanah dan peta penggunaan lahan. 
Tabel 5. Tipe penggunaan lahan di DAS Wae Batu Merah

\begin{tabular}{|c|c|c|c|c|}
\hline \multirow{2}{*}{ No. } & \multirow{2}{*}{ Tipe Penggunaan Lahan } & \multirow{2}{*}{ Kode } & \multicolumn{2}{|c|}{ Luas } \\
\hline & & & (Ha) & $\%$ \\
\hline 1. & Pemukiman & 1 & 408,26 & 59,59 \\
\hline 2. & Semak Belukar & 4 & 215,42 & 31,44 \\
\hline 3. & Hutan Lahan Kering Sekunder & 5 & 61,46 & 8,97 \\
\hline \multicolumn{3}{|c|}{ Total Luas DAS Wae Batu Merah } & 685,14 & 100,00 \\
\hline
\end{tabular}

Sumber: Penelitian lapangan, 2016

\section{Kesesuaian Lahan Akual Untuk Tanaman Pangan Lahan Kering di DAS Wae Batu Merah}

\section{Kelas kesesuaian lahan S3}

Kelas kesesuaian lahan sesuai marjinal (S3) terdapat pada area seluas $116,93 \mathrm{Ha}$ atau $17,06 \%$ dari total luas DAS Wae Batu Merah. Kelas ini terbagi dalam empat sub kelas kesesuaian lahan berdasarkan faktor pembatasnya, yaitu sub kelas (S3a,e,c), (S3a,t,e,c), (S3S,e,c) dan (S3S,t,e,c) (Tabel 7).

a. Sub kelas kesesuaian lahan S3a,e,c memiliki luas $38,78 \mathrm{Ha}$ atau 5,66 \%, dengan faktor pembatas $\mathrm{pH}$ tanah, erodibilitas tanah, zona agroklimat. Sub kelas kesesuaian lahan ini tersebar dalam empat unit lahan, dengan unit lahan terbesar LOdH4 $(24,62 \mathrm{Ha}$ atau 3,594 \%) dan terkecil adalah LObH1 (2,70 Ha atau $0,39 \%)$.

b. Sub kelas kesesuaian lahan S3a,t,e,c memiliki luas 49,64 Ha atau 7,25\%, dengan faktor pembatas $\mathrm{pH}$ tanah, lereng, erodibilitas tanah, zona agroklimat. Sub kelas kesesuaian lahan ini tersebar dalam lima unit lahan, dengan unit lahan terbesar L1dH4 $(26,66 \mathrm{Ha}$ atau $3,891 \%)$ dan terkecil adalah L1dH5 $(0,43 \mathrm{Ha}$ atau $0,062 \%)$.

c. Sub kelas kesesuaian lahan S3S,e,c memiliki luas $10,29 \mathrm{Ha}$ atau $1,50 \%$, dengan faktor pembatas kedalaman efektif, erodibilitas tanah, zona agroklimat. Sub kelas kesesuaian lahan ini tersebar dalam tiga unit lahan, dengan unit lahan terbesar L0dD1 $(5,64 \mathrm{Ha}$ atau $0,823 \%)$ dan terkecil adalah LObD4 (0,03 Ha atau 0,005\%).

d. Sub kelas kesesuaian lahan S3S,t,e,c memiliki luas $18,22 \mathrm{Ha}$ atau 2,66 \%, dengan faktor pembatas kedalaman efektif, lereng, erodibilitas tanah, zona agroklimat. Sub kelas kesesuaian lahan ini tersebar dalam tiga unit lahan, dengan unit lahan terbesar L1bD1 $(15,46 \mathrm{Ha}$ atau 2,256 \%) dan terkecil adalah L1bD4 (0,08 Ha atau 0,012\%).

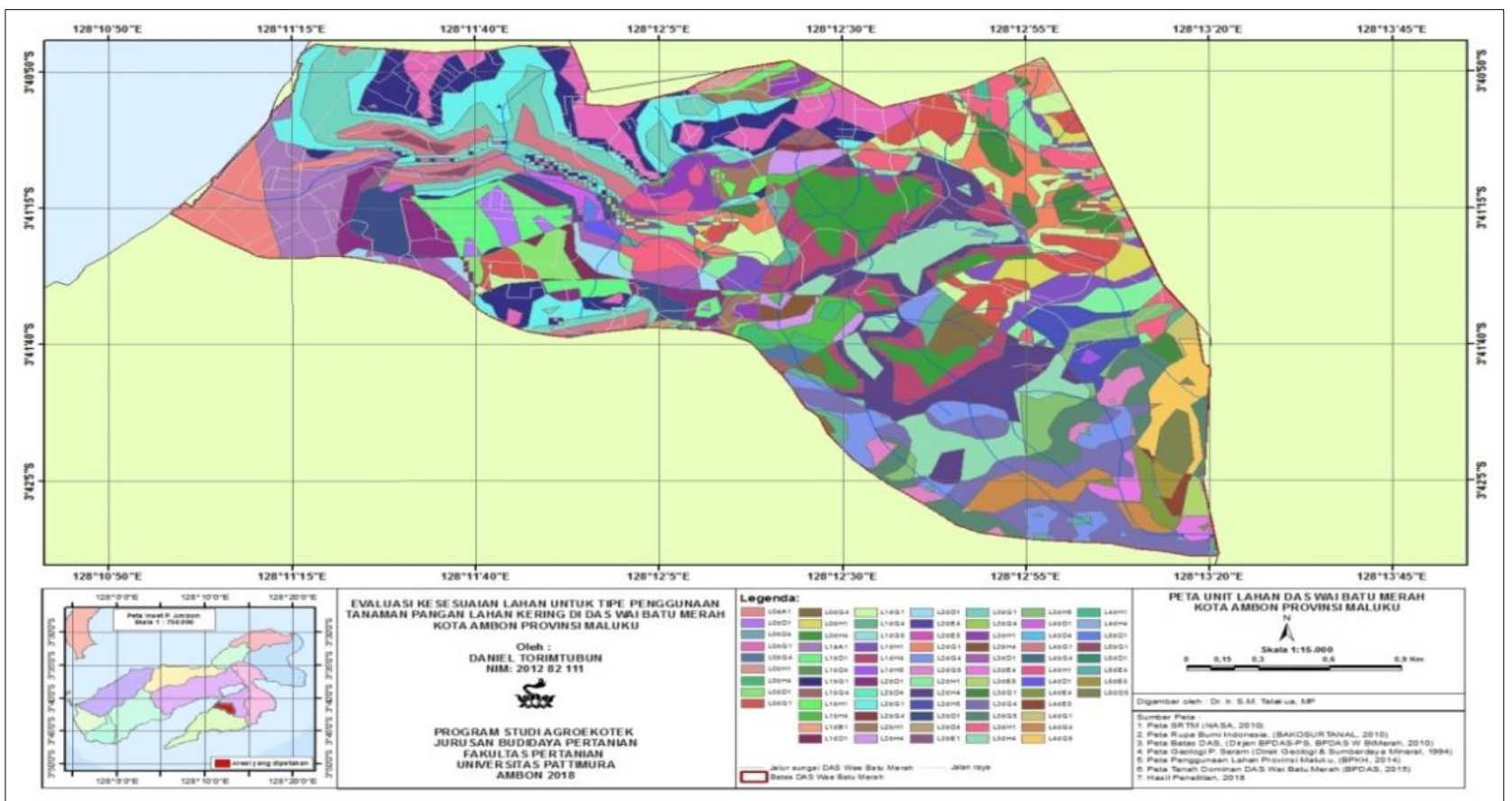

Gambar 1. Peta Unit Lahan di DAS Wae Batu Merah Kota Ambon Provinsi Maluku 
Tabel 6. Kualitas dan karakteristik lahan yang digunakan untuk menentukan Satuan Lahan di DAS Wae Batu Merah

\begin{tabular}{|c|c|c|c|c|c|c|c|c|c|}
\hline \multirow{2}{*}{ No } & \multirow{2}{*}{$\begin{array}{c}\text { Jenis } \\
\text { Tanah }\end{array}$} & \multicolumn{3}{|c|}{ Media perakaran (rc) } & \multirow{2}{*}{$\begin{array}{c}\text { Penyiapan } \\
\text { Lahan (lp) } \\
\text { Batuan } \\
\text { Permukaan }\end{array}$} & \multirow{2}{*}{$\begin{array}{c}\text { Ketinggian } \\
\text { dari } \\
\text { permukaan } \\
\text { laut } \\
\text { (mdpl) }\end{array}$} & \multirow{2}{*}{$\begin{array}{c}\begin{array}{c}\text { Retensi } \\
\text { hara } \\
(\mathrm{nr})\end{array} \\
\mathrm{pH}\end{array}$} & \multicolumn{2}{|c|}{ Bahaya erosi (eh) } \\
\hline & & $\begin{array}{l}\text { Drainase } \\
\text { tanah }\end{array}$ & $\begin{array}{l}\text { Tekstur } \\
\text { tanah }\end{array}$ & $\begin{array}{c}\text { Kedalama } \\
\text { n efektif }\end{array}$ & & & & $\begin{array}{c}\text { Lereng } \\
(\%)\end{array}$ & $\begin{array}{c}\text { Erodibilita } \\
\text { s }\end{array}$ \\
\hline 1 & Aluvial & Baik-sedang & $\mathrm{Ak}$ & $>35 \mathrm{~cm}$ & Tidak ada & 11 & 6,0 & $0-2$ & 0,178 \\
\hline 2 & Gleisol & Baik & $\mathrm{ah}, \mathrm{s}$ & $\geq 97 \mathrm{~cm}$ & Tidak ada & 140 & 5,0 & 15 & 0,38 \\
\hline 3 & Kambisol & Baik & h, ak & $\geq 97 \mathrm{~cm}$ & Tidak ada & 45 & 6,8 & 20 & 0,22 \\
\hline 4 & Podsolik & Baik & ah, s & $110 \mathrm{~cm}$ & Tidak ada & 110 & 5,0 & 20 & 0,225 \\
\hline 5 & Rendzina & Baik & s, sh & $42 \mathrm{~cm}$ & Ada & 122 & 6,6 & 25 & 0,28 \\
\hline 6 & Litosol & Baik & $\mathrm{S}$ & $24 \mathrm{~cm}$ & Tidak ada & 23 & 6,5 & 20 & 0,175 \\
\hline
\end{tabular}

Keterangan: Tekstur Tanah: Halus (h): liat, liat berpasir, liat berdebu; Agak halus (ah): lempung berliat, lempung liat berpasir, lempung liat berdebu; Sedang (s): lempung berpasir sangat halus, lempung, lempung berdebu, debu; Agak kasar (ak): lempung berpasir; B : berat. Erosi: SR: sangat ringan; R: ringan; S: sedang.

Tabel 7. Kesesuaian lahan aktual untuk tanaman pangan lahan kering di DAS Wae Batu Merah

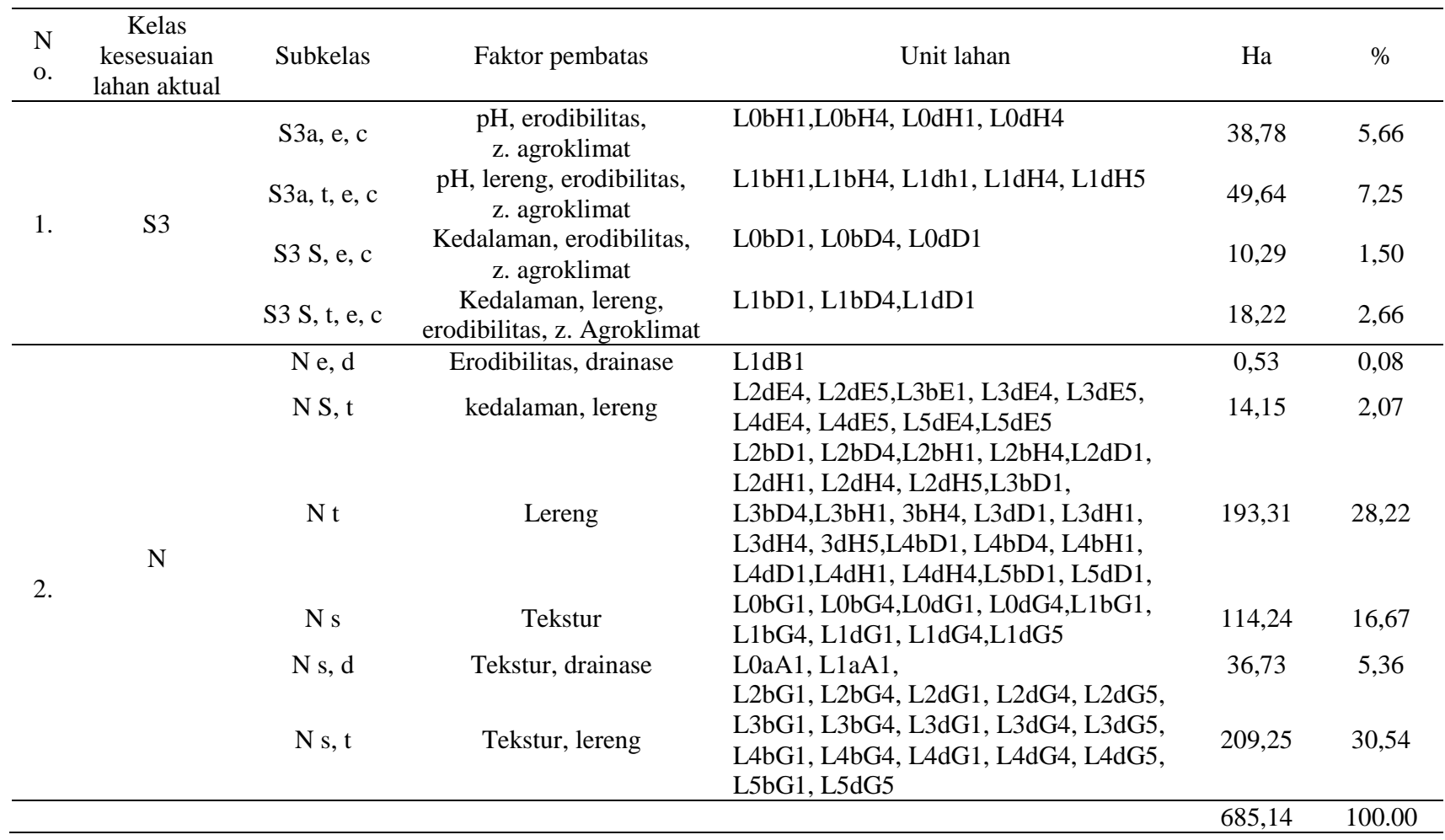

\section{Kelas kesesuaian lahan $\mathbf{N}$}

Kelas kesesuaian untuk lahan tidak sesuai (N) terdapat pada area seluas 568,21 Ha atau 82,94\% dari total luas DAS Wae Batu Merah. Kelas ini terbagi dalam tiga sub kelas kesesuaian lahan, yaitu sub kelas $(\mathrm{Ne}, \mathrm{d}),(\mathrm{NS}, \mathrm{t}),(\mathrm{Nt}),(\mathrm{N} \mathrm{s}),(\mathrm{Ns}, \mathrm{d})$, dan $(\mathrm{Ns}, \mathrm{t})$.

a. Sub kelas kesesuaian lahan Ne,d memiliki luas 0,53 $\mathrm{Ha}$ atau 0,077 \%, dengan faktor pembatas erodibilitas tanah dan drainase tanah. Sub kelas kesesuaian lahan ini hanya terdapat pada satu unit lahan yaitu L1dB1

b. Sub kelas kesesuaian lahan NS,t memiliki luas $14,15 \mathrm{Ha}$ atau $2,07 \%$, dengan faktor pembatas kedalaman efektif dan lereng. Sub kelas kesesuaian lahan ini tersebar dalam sembilan unit lahan, dengan unit lahan terbesar L3dE4 $(4,35 \mathrm{Ha}$ atau $0,635 \%)$ dan terkecil adalah L2dE4 $(0,05 \mathrm{Ha}$ atau $0,01 \%$ ).

c. Sub kelas kesesuaian lahan Nt memiliki luas 193,31 Ha atau 28,22 \%, dengan faktor pembatas lereng. Sub kelas kesesuaian lahan ini tersebar dalam dua puluh empat unit lahan, dengan unit lahan terbesar L2dH4 (24,62 Ha atau 3,594 \%) dan terkecil adalah L4bD4 (0,0 Ha atau $0,0 \%)$.

d. Sub kelas kesesuaian lahan $\mathrm{N}$ s memiliki luas $114,24 \mathrm{Ha}$ atau 16,67 \%, dengan faktor pembatas tekstur. Sub kelas kesesuaian lahan ini tersebar dalam sembilan unit lahan, dengan unit lahan terbesar L1bG1 $(32,79 \mathrm{Ha}$ atau 4,786 \%) dan 
lauasan terkecil adalah L1dG5 $(0,10 \mathrm{Ha}$ atau $0,014 \%$ ).

e. Sub kelas kesesuaian lahan $\mathrm{N}$ s,d memiliki luasan $36,73 \mathrm{Ha}$ atau $5,36 \%$. Sub kelas ini memiliki faktor pembatas tekstur dan drainase. Sub kelas kesesuaian lahan ini tersebar dalam dua unit lahan, dengan unit lahan terbesar L1aA1 $(21,01 \mathrm{Ha}$ atau $3,067 \%)$ dan lauasan terkecil adalah $\mathrm{L}(15,71 \mathrm{Ha}$ atau 2,293\%).

f. Sub kelas kesesuaian lahan N s, t memiliki luasan 209,25 Ha atau 30,54\%, dengan faktor pembatas tekstur tanah dan lereng. Sub kelas kesesuaian lahan ini tersebar dalam tujuh belas unit lahan, dengan unit lahan terbesar L3bG1 $(35,02 \mathrm{Ha}$ atau $5,111 \%)$ dan terkecil adalah L3bG4 $(0,02 \mathrm{Ha}$ atau $0,004 \%)$.

\section{Kesesuaian Lahan Potensial untuk Tanaman Pangan Lahan Kering di DAS Wae Batu Merah}

Kelas kesesuaian S3 dengan Sub kelas pada masing-masing unit lahan yaitu: S3 a, e, c untuk unit lahan (LObH1, LObH4, LOdH1, LOdH4,) S3 a, t, e, c untuk unit lahan (L1bH1, L1bH4, L1dh1, L1dH4, L1dH5,) S3 S, e, c untuk unit lahan (L0bD1, LObD4, L0dD1,) S3 S, t, e, c untuk unit lahan (L1bD1, L1bD4,L1dD1).

Sub kelas S3 a, e, c ditemukan pada unit lahan LObH1,LObH4, LOdH1, LOdH4, dengan faktor pembatas pH tanah, erodibilitas tanah dan zona agroklimat. Untuk faktor pembatas zona agroklimat tidak bisa dilakukan perbaikan. Sedangkan untuk faktor pembatas $\mathrm{pH}$ dapat dilakukan perbaikan dengan cara pengapuran atau penambahan bahan organik dengan tingkat pengelolaan sedang sehingga kelas kesesuaian menjadi S2. Untuk faktor pembatas erodibilitas tanah dapat dilakukan perbaikan dengan cara pembuatan teras, penanaman sejajar kontur dan juga penanaman penutup tanah dengan tingkat pengelolaan sedang sehingga kelas kesesuaian menjadi $\mathrm{S} 2$.

Sub kelas S3 a, t, e, c, ditemukan pada unit lahan L1bH1,L1bH4, L1dh1, L1dH4, L1dH5, dengan faktor pembatas $\mathrm{pH}$ tanah, lereng, erodibilitas tanah dan zona agroklimat. Untuk faktor pembatas zona agroklimat tidak bisa dilakukan perbaikan. Sedangkan untuk faktor pembatas $\mathrm{pH}$ dapat dilakukan perbaikan dengan cara pengapuran atau penambahan bahan organik dengan tingkat pengelolaan sedang sehingga kelas kesesuaian menjadi S2, dan untuk faktor pembatas lereng dan erodibilitas dapat dilakukan perbaikan dengan cara pembuatan teras, penanaman sejajar kontur dan juga penanaman penutup tanah dengan tingkat pengelolaan sedang sehingga kelas kesesuaian menjadi S2.

Sub kelas S3 S, e, c ditemukan pada unit lahan L0bD1, L0bD4, L0dD1 dengan faktor pembatas kedalalam efektif, erodibilitas tanah dan zona agroklimat. Untuk faktor pembatas kedalaman efektif dan zona agroklimat tidak bisa dilakukan perbaikan. Sedangkan untuk faktor pembatas erodibilitas tanah dapat dilakukan perbaikan dengan cara pembuatan teras, penanaman sejajar kontur dan juga penanaman penutup tanah dengan tingkat pengelolaan sedang sehingga kelas kesesuaian menjadi $\mathrm{S} 2$.

Sub kelas S3 S, t, e, c ditemukan pada unit lahan L1bD1, L1bD4, L1dD1 dengan faktor pembatas kedalalam efktif, lereng, erodibilitas tanah dan zona agroklimat. Untuk faktor pembatas kedalaman efektif dan zona agroklimat tidak bisa dilakukan perbaikan. Sedangkan untuk faktor pembatas lereng dan erodibilitas tanah dapat dilakukan perbaikan dengan cara pembuatan teras, penanaman sejajar kontur dan juga penanaman penutup tanah dengan tingkat pengelolaan sedang sehingga kelas kesesuaian menjadi S2.

Kelas kesesuaian $\mathrm{N}$ dengan sub kelas pada masing-masing unit lahan yaitu:

- $\mathrm{N}$ e,d untuk unit lahan L1dB1,

- N S,t, untuk unit lahan L2dE4, L2dE5, L3bE1, L3dE4, L3dE5, L4dE4, L4dE5, L5dE4, L5dE5,

- $\mathrm{N}$ t, untuk unit lahan L2bD1, L2bD4, L2bH1, L2bH4, L2dD1, L2dH1 L2dH, L2dH5, L3bD1, L3bD4, L3bH1, L3bH4, L3dD1, L3dH1, L3dH4, L3dH5, L4bD1, L4bD4, L4bH1 L4dD1, L4dH1, L4dH4, L5bD1, L5dD1,

- N s, untuk unit lahan L0bG1, L0bG4, L0dG1, L0dG4, L1bG1, L1bG4, L1dG1, L1dG4, L1dG5,

- N s,d untuk unit lahan L0aA1, L1aA1,

- N s,t untuk unit lahan L2bG1, L2bG4, L2dG1, L2dG4, L2dG5, L3bG1, L3bG4, L3dG1, L3dG4, L3dG5, L4bG1, L4bG4, L4dG1, L4dG4, L4dG5, L5bG1, L5dG.

Pada Sub kelas Ne,d, N S,t, N t, N s, N s,d, N s,t, dengan faktor pembatas erodibilitas dan drainase $(\mathrm{Ne}, \mathrm{d})$, kedalaman dan lereng $(\mathrm{Ns}, \mathrm{t})$, lereng $(\mathrm{Nt})$, tekstur $(\mathrm{N} \mathrm{s})$, tekstur dan drainase $(\mathrm{N} \mathrm{s,d})$, tekstur dan lereng $(\mathrm{N} \mathrm{s,t})$. sedangkan untuk kelas $\mathrm{N}$ tidak dapat dilakukan perbaikan karena kelas ini merupakan lahan yang tidak sesuai karena mempunyai faktor pembatas yang sangat berat dan atau sulit diatasi.

\section{KESIMPULAN}

1. Terdapat 2 kelas kesesuaian lahan bagi tanaman pangan lahan kering di DAS Wae Batu Merah yaitu, kelas kesesuaian lahan S3 seluas 116,93 Ha atau $17,06 \%$, dengan faktor pembatas $\mathrm{pH}$ tanah, erodibilitas, zona agroklimat, lereng, kedalaman efektif, dan kelas kesesuaian $\mathrm{N}$ terdapat pada area seluas $568,21 \mathrm{Ha}$ atau $0,077 \%$ dengan faktor pembatas erodibilitas, drainase, kedalaman efektif, lereng, dan tekstur.

2. Faktor-faktor pembatas untuk tipe penggunaan lahan tanaman pangan lahan kering di DAS Wae Batu Merah sebagai berikut: lereng, kedalaman efektif, tekstur, drainase, lereng, pH, erodibilitas, zona agroklimat. Kelas kesesuaian lahan potensial setelah dilakukan perbaikan menjadi kelas S2 dengan faktor pembatas $\mathrm{pH}$ tanah, lereng, dan erodibilitas. 


\section{DAFTAR PUSTAKA}

Direktur Jenderal Rehabilitasi Lahan dan Perhutanan Sosial Departemen Kehutanan. 2009. Petunjuk Teknis Penyusunan Data Spasial Lahan Kritis. Dirjen RPLS-Departemen Kehutanan. Jakarta.

Hardjowigeno, S. dan Widiatmaka. 2007. Evaluasi Kesesuaian Lahan dan Perencanaan Tata Guna Lahan. Yogyakarta: Gadjah Mada University Press.

Manuputty, M.P.F. 2017. Evaluasi kualitas lingkungan dan daya dukung DAS Wae Batu Merah Kota Ambon. Tesis. Pengelolaan Lahan. Program Pasca Sarjana, Unpatti.

Nganji, M.U., B.H. Simanjuntak, dan Suprihati. 2018. Evaluasi kesesuaian lahan komoditas pangan utama di Kecamatan Umbu Ratu Nggay Barat Kabupaten Sumba Tengah. Agritech 38: 172177. DOI: $10.22146 /$ agritech. 33147

Osok, R.M, S.M Talakua, dan D. Supriadi. 2018. Penetapan kelas kesesuaian lahan dan arahan Rehabilitasi lahan DAS wai Batu Merah Kota
Ambon Provinsi Maluku. AGROLOGIA 7: $32-$ 41. DOI: $10.30598 / a . v 7 i 1.355$

Panagos, P., P. Borrelli, K. Meusburger, C. Alewell, E. Lugato, and L. Montanarella. 2015. Estimating the soil erosion cover-management factor at the European scale. Land Use Policy 48: 38-50. DOI: 10.1016/j.landusepol.2015.05.021

Sarkar, A., A. Ghosh, and P. Banik. 2014. Multi-criteria land evaluation for suitability analysis of wheat: a case study of a watershed in eastern plateau region, India. Geo-Spatial Information Science 17: $119-128$. DOI: $10.1080 / 10095020$. 2013.774106

Sitorus. 1985. Evaluasi Sumberdaya Lahan. Bandung: Tarsito.

Sitorus, S.R.P., M. Mulyani, dan D.R. Panuju. 2011. Konversi lahan pertanian dan keterkaitannya dengan kelas kemampuan lahan serta hirarki wilayah di Kabupaten Bandung Barat. Jurnal Tanah dan Lingkungan 13: 49-57. DOI: http://dx.doi.org/10.29244/jitl.13.2.49-57 